\title{
An Exploration of Dynamical Relationships between Macroeconomic Variables and Stock Prices in Korea*
}

\author{
Jung Wan Lee ${ }^{1}$, Tantatape Brahmasrene ${ }^{2}$ \\ Received: May 30, 2018 Revised: July 14, 2018 Accepted: July 30, 2018
}

\begin{abstract}
This paper examines short-run and long-run dynamic relationships between selected macroeconomic variables and stock prices in the Korea Stock Exchange. The data is restricted to the period for which monthly data are available from January 1986 to October 2016 (370 observations) retrieved from the Economic Statistics System database sponsored by the Bank of Korea. The study employs unit root test, cointegration test, vector error correction estimates, impulse response test, and structural break test. The results of the Johansen cointegration test indicate at least three cointegrating equations exist at the 0.05 level in the model, confirming that there is a long-run equilibrium relationship between stock prices and macroeconomic variables in Korea. The results of vector error correction model (VECM) estimates indicate that money supply and short-term interest rate are not related to stock prices in the short-run. However, exchange rate is positively related to stock prices while the industrial production index and inflation are negatively related to stock prices in the short-run. Furthermore, the VECM estimates indicate that the external shock, such as regional and global financial crisis shocks, neither affects changes in the endogenous variables nor causes instability in the cointegrating vector. This study finds that the endogenous variables are determined by their own dynamics in the model.
\end{abstract}

Keywords: Stock Prices, Exchange Rate, Macroeconomic Variables, Global Financial Crisis, Korea.

JEL Classification Code: G15, F31, E44, F37, G01.

\section{Introduction}

Perhaps the two theories about the dynamic relationship between macroeconomic variables such as exchange rates

* The paper with the title ["Long-run and Short-run Dynamic Relationships between Macroeconomic Variables and Stock Prices in Korea"] was presented initially at 2018 International Conference on Business and Economics (ICBE2018) and the 14th International Conference of KODISA that was held in Seoul, South Korea, June 25-27, 2018. The paper has been recognized as one of Best Paper Awards at ICBE2018 conference. This paper is a substantially revised and expanded version of the paper presented at ICBE2018 conference. The authors have taken into account all the comments of Editors, Session Chairs and Reviewers in the revised manuscript. The authors greatly appreciate Editors, Session Chairs and Reviewers for their valuable comments, interest in and support of this research.

1 First Author. Assistant Professor, Administrative Sciences Department, Metropolitan College, Boston University, Boston, USA Email: jwlee119@bu.edu

2 Corresponding Author. Professor of Finance \& International Business, College of Business, Purdue University Northwest, [Postal Address: 1401 S. US. Hwy. 421, Westville, IN 46391, USA] Email: tapeb@pnw.edu and stock prices are the traditional approach and the portfolio approach. Although, these approaches have long been discussed, has not reached a consensus. The traditional approach claims that depreciation of the local currency makes local firms more competitive, leading to an increase in their exports and consequently higher stock prices. This implies a positive correlation between macroeconomic variables, exchange rates and stock prices. It also suggests that the fluctuation of exchange rates leads to the changes in stock prices. Conversely, the portfolio approach argues that an increase in stock prices induces investors to demand more domestic assets and thereby causes an appreciation in the local currency. Thus, changes in stock prices are inversely related to exchange rates.

Stock prices are generally interpreted as representing the present values of future cash flows of firms, reacting to exchange rate changes and forming the link among future income, interest rates, current investment and consumption decisions (Zhao, 2010). In the floating exchange rate system, the exchange rate is essentially determined by a country's current account balance or trade balance. As a result, exchange rate fluctuations affect to some extent, international competitiveness and trade balance. 
Consequently, it affects real income and stock prices, especially the stock price of export oriented enterprises.

Two models explain relationship between macroeconomic variables and stock prices. The flow-oriented model (Dornbusch \& Fisher, 1980) claims a positive linkage between selected macroeconomic variables and stock prices. Local currency depreciation leads to greater competitiveness of local firms given that their exports will be cheaper in international trade. Higher exports will increase the domestic income and since the firms' stock prices are evaluated as the present value of the firms' future cash flows, they will also increase.

The stock-oriented model (Branson, Halttunen, \& Masson, 1977) of exchange rates asserts that the exchange rate serves to equalize the supply and demand for assets such as stocks and bonds. This model determines the exchange rate dynamics by giving the capital account a pivotal role. Since the values of financial assets are determined by the present values of their future cash flows, expectations of relative currency values play a considerable role in the price movements of the financial assets. Therefore, stock prices may affect, or be affected by, exchange rate dynamics (Zhao, 2010). As a result, if selected macroeconomic variables (i.e. common factors) influence the two variables, stock prices may be reciprocally associated with exchange rate dynamics and macroeconomic variables or be influenced by the exchange rate and macroeconomic variables behavior.

The research goals of this study are to fill the gap in the literature and to provide additional evidence on both the short-run and long-run dynamic relationships between selected macroeconomic variables and both exchange rates and stock prices in the Korean Stock Exchange.

\section{Literature Review}

The fluctuation of stock prices has long intrigued economists, financial analysts, investors as well as academia. A plethora of literatures have examined and studied many factors that seem to have an impact on stock prices most notably, macroeconomics variables and monetary policy. Two major influences on stock prices are discussed including macroeconomic variables and external shocks.

\subsection{Stock Prices and Macroeconomic Variables}

Scores of studies conducted to examine the relationship between stock prices and macroeconomic variables are identified here by regions.
Three Largest European Economy. The study of the relationship of stock prices and macroeconomic variables by Peiro (2016) in three largest European economy namely, France, Germany and the United Kingdom (UK) found the industrial production index and interest rates affected stock prices in all three countries. In addition, Pier found that the results differed noticeably from the United States (US), where the only factor affecting US stock prices was the industrial production index (IPI).

The Middle East. Likewise, investigation of stock prices on the Amman Stock Exchange in Jordan with a set of macroeconomic variables discovered a bi-directional longrun relationship between stock prices, credit to private sector, weighted average interest rate on time deposit, as well as, the consumer price index or CPI (Al-Majali \& AlAssaf, 2014). Furthermore, long-run relationships existed between stock prices and macroeconomic variables such as interest rates, money supply, exchange rates, the industrial production index, gold prices and the $\mathrm{CPI}$ in the Turkish market (Büyükşalvarc \& Abdioğlu, 2010; Alrub, Tursoy, \& Rjoub, 2016).

Emerging Economies. In emerging economies specifically Brazil, Russia, India and China (BRIC), Gay (2016) revealed no significant relationship between stock prices and macroeconomic variables such as exchange rate and oil prices. Yet, Raja and Kalyanasundaram (2010) found that inflation had significant impact on stock prices in India, whereas in Brazil, gross domestic product (GDP), inflation and interest rates showed significant relationship with stock prices. Moreover, a significant relationship existed between stock prices in emerging markets and macroeconomic variables such as money supply, goods prices, real activity and exchange rates while local factors seem to have more weight in affecting the stock prices as compared to global factors (Bilson, Brailsford \& Hooper, 2009).

The Indian Subcontinent. A handful of literatures on the relationship of stock prices and various macroeconomic variables in the Indian market, such as Agrawalla and Tuteja (2008), Sampath (2011), Kumar (2011), Sangmi and Hassan (2013), Kotha and Sahu (2016), and Mangala and Rani (2015) reveals findings that vary depending on the time period and data set. Agrawalla and Tuteja (2008), Sampath (2011), and Kotha and Sahu (2016) used data from the Bombay Stock Exhange (BSE) whereas the rest employed data from the National Stock Exchange of India (NSE). Both Agrawalla and Tuteja (2008) and Sampath (2011) exposed uni-directional causality and significant positive relationship between economic growth (proxied by industrial production index) and stock prices.

According to Kotha and Sahu (2016), there is bidirectional causality between stock prices and exchange 
rate in the short-run, and significant relationship between stock prices and the wholesale price index, money supply as well as treasury bill rates in the long-run. However, the study by Kumar (2011) which used stock prices data from the NSE, found no co-integration between the stock prices with macroeconomic variables such as exchange rate, balance of trade (BOT), foreign direct investment (FDI) and the industrial production index. Further, no significant causality was found between stock prices and the wholesale price index which implies that the real sector does not affect the stock market (Kumar, 2011). This was supported by findings from Sangmi and Hassan (2013) that showed no significant relationship between NSE stock prices with the variables examined such as inflation, the industrial production index, money supply, gold prices and interest rates with the exception of a negative relationship with exchange rates whereby an increase in exchange rate caused lower stock prices. Reinvestigation of the relationship between NSE stock prices and macroeconomic variables (inflation rate, exchange rate, industrial production index, gold price, money supply and short-term interest rate), Mangala and Rani (2015) found short-run causality from exchange rate to stock prices and from stock prices to money supply and inflation rate. Additionally, long-run causality was found from stock prices to short-term interest rate and money supply.

Addressing the relationship between stock prices and macroeconomic variables such as money supply, inflation, exchange rate, and GDP growth rate in Pakistan from 1961 to 2009, Ahmad, Ahmad, Khan and Javaid (2012) revealed that only inflation and exchange rate had significant negative impact on stock prices whereas GDP growth rate and money supply showed a weak positive impact and insignificant positive impact, respectively.

North and South Asia. Further study of the relationship between stock prices and macroeconomic variables, such as employment rate, exchange rate, GDP, inflation and money supply in Taiwan from 2003 to 2008 detected that only the exchange rates and GDP had a significant impact on the stock prices (Singh, Mehta, \& Varsha, 2011).

For Southeast Asian countries, Kabir, Bashar and Masih (2014), using the Kuala Lumpur Composite Index (KLCl) data; and Hussin, Muhammad, Abu and Awang (2012), using the Kuala Lumpur Syariah Index (KLSI) data, examined the relationship between stock prices and macroeconomic variables in Malaysia. Both studies displayed a significant relationship between stock prices and exchange rates suggesting that Malaysian listed companies might be dealing with international trade directly or indirectly Also, the industrial production index and CPI have a significant positive relationship with stock prices whereas money supply and exchange rates are negatively related to stock prices (Hussin et al., 2012). In addition, a significant long-run relationship between stock prices and macroeconomic variables, such as industrial production index, money supply, oil prices and nominal exchange rates were discovered in Thailand for the period of 1992 to 1997 (pre financial crisis). However, for the period of post financial crisis in Thailand (1997 to 2003), the study found no relationship between stock prices and macroeconomic variables such as industrial production index and oil prices, which might be a result of government intervention and control (Brahmasrene \& Jiranyakul, 2007). A study by Hussainey and $\mathrm{Ngoc}$ (2009) on the effects of macroeconomic variables, such as interest rate and industrial production index on Vietnamese stock prices for the period of 2001 to 2008 found that only the industrial production index had positive effect on stock prices.

Finally, a literature review by Bahmani-Oskooee and Saha (2015) concluded that the relationship between stock prices and exchange rate is only short-run and no long-run relationship is found. The findings from the reviewed literatures were very specific regarding the study period, the countries chosen, as well as other macroeconomic variables selected.

\subsection{Stock Prices and External Shocks}

Studies on relationship between stock prices and external shocks identify the following results. Stock prices in Czech Republic, Hungary, Poland and Slovenia were found to be significantly affected by Euro area monetary policy as compared to their own domestic monetary policy implying that financial integration resulted in the sensitivity of stock prices to external shocks (Pirovano, 2012).

The 1997 Asian financial crisis (July 1997 - December 1999) was a period of financial crisis that gripped much of East Asia beginning in July 1997 and raised fears of a worldwide economic meltdown due to financial contagion. In South Korea, the banking sector was burdened with nonperforming loans as its large corporations were funding aggressive expansions. During that time, many businesses ultimately failed to ensure returns and profitability. In the wake of the Asian market downturn, Moody's lowered the credit rating of South Korea from A1 to A3, on 28 November 1997, and downgraded again to B2 on 11 December 1997 (Hahm, 2005; Lim, 2005). The downgrading contributed to a further decline in South Korean shares since stock markets were already bearish in November 1997. First, the South Korean won weakened to more than 1,700 per US dollar from around 800 , but later managed to recover by the end of 1999. Also, its national debt-to-GDP ratio more than doubled (approximately $13 \%$ to $30 \%$ ) as a result of the crisis (Hahm, 2005; Lim, 2005). 


\subsection{Hypotheses}

Based on the aforementioned literature, macroeconomic variables and exchange rates are likely related to stock prices. This study includes money supply (M2), industrial production index (IPI), inflation (consumer price index), foreign exchange rates and short-term interest rate (i.e. certificate of deposit). Accordingly, the following hypotheses are considered:

Hypothesis 1: There is a long-run equilibrium relationship between stock prices and macroeconomic variables in Korea

Hypothesis 2: Money supply (M2) is related to stock prices in the short-run.

Hypothesis 3: Industrial Production Index (IPI) is related to stock prices in the short-run.

Hypothesis 4: Inflation (CPI) is related to stock prices in the short-run.

Hypothesis 5: Exchange rate (FX_USD) is related to stock prices in the short-run.

Hypothesis 6: Short-term interest rate (CD) is related to stock prices in the short-run.

Hypothesis 7: External shocks are related to stock price dynamics in the short-run.

\section{Data and Methods}

This section describes the data and outlines the methodology used in the selection of indicators. The sample is restricted to the period for which monthly data are available, which is from January 1986 to October 2016 (370 observations). All of the monthly time series data below are collected and retrieved from the Economic Statistics System database sponsored by the Bank of Korea.

\subsection{Variables and Indicators}

Korea Stock Exchange Market Price. The Korea Composite Stock Price Index (KOSPI) is used as a proxy of the Korean stock market prices. This major stock market index tracks the general performance of all common shares listed on the Korean Stock Exchange. The KOSPI index is a capitalization-weighted index of all common shares on the Korean Stock Exchange. The index was developed with a base value of 100 as of January 4, 1980. Monthly average of this index is used in this study.

Money Supply (M2): M2 is a measure of the money supply that includes all elements of $\mathrm{M} 1$ as well as "near money." M1 includes cash and checking deposits, while near money refers to savings deposits, money market securities, mutual funds and other time deposits. These assets are less liquid than M1 and not as suitable as exchange mediums, but they can be quickly converted into cash or checking deposits.

Industrial Production Index (IPI): IPI is an economic indicator that measures real output for all facilities located in an economy manufacturing, mining, and electric, and gas utilities. The index is compiled on a monthly basis to bring attention to short- term changes in industrial production. It measures movements in production output and highlights structural developments in the economy. Growth in the production index from month to month is an indicator of growth in the industry.

Consumer Price Index (CPI): CPI is a measure that examines the weighted average of prices of a basket of consumer goods and services, such as transportation, food and medical care. It is calculated by taking price changes for each item in the predetermined basket of goods and averaging them. Changes in the $\mathrm{CPI}$ are used to assess price changes associated with the cost of living. CPI is one of the most frequently used statistics for identifying periods of inflation or deflation.

Foreign Exchange Rates (FX_USD): The Korean won per the U.S. dollar (USD) is selected based on the volume of international trade with South Korea. The time series data is a monthly adjusted average. In effect, $F X \_U S D$ is the logarithm of the nominal exchange rate of Korean won per U.S. dollar.

Certificate of Deposit (CD): A certificate of deposit is a savings certificate with a fixed maturity date, specified fixed interest rate, and can be issued in any denomination aside from the minimum investment requirements which differ among instruments. A CD restricts access to the funds until the maturity date of the investment. CDs are generally issued by commercial banks. When the CD matures, the entire amount of principal as well as interest earned is available for withdrawal.

External Shocks (Dummy Variable): In addition to the 1997 Asian financial crisis (July 1997 - December 1999), the 2007 Global Financial Crisis (August 2007 - December 2009) may also cause a structural break in the trend of stock prices in the Korean stock market. Because the global financial crisis would introduce some changes in the implementation of monetary policy, for example, from monetary targeting to interest rate targeting, this would introduce substantial instability in the system.

A dummy variable is used to examine the impacts of the 1997 Asian financial crisis and the 2007 global financial crisis on the Korean stock market. However, the dummy here is used as an exogenous variable because it is assumed not to be systematically affected by changes in the 
endogenous variables of the model (Brahmasrene, Huang, \& Sissoko, 2014). A dummy variable with a value of zero will cause the variable's coefficient to disappear, and a dummy with a value one will cause the coefficient to act as a supplemental intercept in the regression model. Hence, the Asian financial crisis period (July 1997 - December 1999) or the global financial crisis (August 2007 - December 2009) variable equals one if the month falls into one of the crisis period and zero if it falls outside these periods.

\subsection{Descriptive Statistics of Data}

All these time series data have been collected and retrieved from the Economic Statistics System database sponsored by the Bank of Korea. For all these time series data are reported on a monthly basis and employed for the period from January 1986 to October 2016 (370 observations). Table 1 displays descriptive statistics along with various summary statistics for the time series. Table 2 displays the results of Pearson correlation analysis between the time series.

Table 1. Descriptive Statistics of KOSPI and Macroeconomic Variables (monthly, 1986-2016)

\begin{tabular}{|c|c|c|c|c|c|}
\hline & Unit & Minimum & Maximum & Mean & $\begin{array}{c}\text { Std. } \\
\text { Deviation }\end{array}$ \\
\hline KOSPI & & 157 & 2153 & 1087 & 563 \\
\hline M2 & Billion Won & 43133 & 2391059 & 881630 & 685077 \\
\hline IPI & & 50 & 111 & 78 & 18 \\
\hline CPI & & 34 & 111 & 75 & 23 \\
\hline FX_USD & & 666 & 1706 & 1004 & 206 \\
\hline CD & $\%$ & 1.34 & 23.10 & 9.07 & 6.40 \\
\hline
\end{tabular}

Table 2. Pearson Correlations $(\mathrm{N}=370)$

\begin{tabular}{|c|c|c|c|c|c|}
\hline & KOSPI & M2 & IPI & CPI & FX_USD \\
\hline M2 & $.891^{* *}$ & & & & \\
\hline IPI & $.844^{* *}$ & $.948^{* * *}$ & & & \\
\hline CPI & $.840^{* *}$ & $.968^{* *}$ & $.978^{* *}$ & & \\
\hline FX_USD & $.241^{* *}$ & $.590^{* *}$ & $.656^{* *}$ & $.662^{* *}$ & \\
\hline CD & $-.699^{* *}$ & $-.866^{* *}$ & $-.880^{* *}$ & $-.923^{* *}$ & $-.664^{* *}$ \\
\hline
\end{tabular}

Note: Correlation is significant ${ }^{*}$, at the 0.05 level and ${ }^{* *}$, at the 0.01 level (2-tailed).

\subsection{Unit Root Test}

It is well known in the literature that the data generating process for many economic variables are characterized by stochastic trends that might result in spurious inference if the time series properties are not carefully investigated. A time series is said to be stationary if the mean and autocovariances of the series do not depend on time. Any series that is not stationary is said to be non-stationary (i.e. it has a unit root). The formal method to test the stationarity of a series is the unit root test. There are several well-known tests for this purpose based on individual time series: the augmented Dickey-Fuller (ADF) unit root test (Dickey \& Fuller, 1979, 1981), the Phillips-Perron (PP) unit root test (Phillips \& Perron, 1988), and the Kwiatkowski, Phillips, Schmidt and Shin (KPSS) unit root test (Kwiatkowski, Phillips, Schmidt, \& Shin, 1992), among others.

Table 3 reports the results of unit root tests. All test equations were tested by the method of least squares, including an intercept, but no time trend in the model. Probabilities for all tests assume asymptotic normality. In the ADF and PP tests, an optimal lag in the tests is automatically selected based on Schwarz Info Criterion and the lag length (bandwidth) in the tests is automatically selected based on the Newey-West estimator (Newey \& West, 1994) using the Bartlett kernel function. In ADF and PP tests, probability values for rejection of the null hypothesis of a unit root are employed at the 0.05 level based on MacKinnon (1996) one-sided p-values. KPSS tests the null hypothesis: a series has no unit root (stationary), while the alternative hypothesis assumes that the series has a unit root (non-stationary). In KPSS test, the probability values for rejection of the null hypothesis are based on Kwiatkowski, Phillips, Schmidt and Shin (1992) LM statistic p-values.

Table 3. Results of Unit Root Tests

\begin{tabular}{|c|c|c|c|c|c|c|}
\hline Tests & ADF(0) & ADF(1) & PP(0) & PP(1) & KPSS(0) & KPSS(1) \\
\hline KOSPI & -2.057 & $-13.496^{* *}$ & -2.170 & $-13.447^{* *}$ & $1.796^{* *}$ & 0.161 \\
\hline M2 & -1.878 & $-9.891^{* *}$ & -1.891 & $-9.985^{* *}$ & $2.291^{* *}$ & 0.342 \\
\hline IPI & -1.372 & $-10.703^{* *}$ & -1.375 & $-10.498^{* *}$ & $2.320^{* *}$ & 0.217 \\
\hline CPI & -2.170 & $-12.497^{* *}$ & -2.259 & $-13.247^{* *}$ & $2.323^{\star *}$ & 0.373 \\
\hline FX_USD & -1.613 & $-13.563^{* *}$ & -1.702 & $-11.053^{\star *}$ & $1.369^{* *}$ & 0.056 \\
\hline CD & -0.357 & $-8.667^{* *}$ & -0.320 & $-11.887^{* *}$ & $2.291^{* *}$ & 0.062 \\
\hline
\end{tabular}

Note: The numeric values in cells are t-statistic. Probability values for rejection of the null hypothesis are employed at the $5 \%$ significant level ${ }^{*}, p$-value $<0.05$ and ${ }^{* *}$, p-value $\left.<0.01\right)$.

\section{Results}

A linear combination of two or more non-stationary series may be stationary (Engle \& Granger, 1987). If such a stationary linear combination exists, the non-stationary time series are said to be cointegrated. If these variables are cointegrated, then there exists long-run equilibrium among the variables. In other words, if the variables are cointegrated, there is a long-run relationship, and there exists a force to converge into long-run equilibrium. 


\subsection{Cointegration Test}

There are two test methods to identify whether there is a long-run relationship among variables: the Engle-Granger single equation test method (Engle \& Granger, 1987) and the Johansen conintegration test (Johansen, 1988). Cheung and Lai (1993) report that the Johansen approach is more efficient than the Engle-Granger single equation test method because the maximum likelihood procedure has useful large and finite sample properties. The Johansen cointegration test models each variable as a function of all the lagged endogenous variables in the system. In addition, the procedure uses two ratio tests: a trace test and a maximum eigenvalue test, to test the number of cointegration relationships. Both tests can be used to determine the number of cointegrating vectors present, although they do not always indicate the same number of cointegrating vectors. If trace statistics and maximum eigenvalue statistics yield different results, the result of the maximum eigenvalue test is preferred due to the benefit of carrying out separate tests on each eigenvalue.

Table 4 presents the results of the Johansen cointegration test. The test equation was tested by the method of least squares. The regression model allows for a linear deterministic trend in the data and includes an intercept, but no trend in vector autoregressive models. Lags interval in first differences is 1 to 4 . For the two likelihood ratio test statistics, the probability value for rejection of the null hypothesis of no cointegration is based on the MacKinnon, Haug and Michelis (1999) p-values. The null hypothesis of no cointegration is rejected at the $5 \%$ significance level. Both the trace and the maximum eigenvalue tests indicate that at least three cointegrating equations exist at the 0.05 level. Therefore, the null hypothesis of no cointegration can be rejected at the 0.05 level. Considering the results of the Johansen cointegration test in Table 4, this study supports hypothesis 1 that there is a long-run equilibrium relationship between stock prices and macroeconomic variables in Korea.

Table 4. Results of Johansen Cointegration Test

\begin{tabular}{|c|c|c|}
\hline $\begin{array}{c}\text { Number of } \\
\text { cointegration }(r)\end{array}$ & Trace statistic & $\begin{array}{c}\text { Maximum } \\
\text { eigenvalue statistic }\end{array}$ \\
\hline$r=0$ & $157.044(95.753)^{\star *}$ & $61.330(40.077)^{\star *}$ \\
\hline$r \leq 1$ & $95.713(69.818)^{\star *}$ & $39.651(33.876)^{\star *}$ \\
\hline$r \leq 2$ & $56.062(47.856)^{\star *}$ & $29.888(27.584)^{*}$ \\
\hline$r \leq 3$ & $26.173(29.797)$ & $14.172(21.131)$ \\
\hline$r \leq 4$ & $12.000(15.494)$ & $7.928(14.264)$ \\
\hline$r \leq 5$ & $0.072(3.841)$ & $0.072(3.841)$ \\
\hline
\end{tabular}

Note: Regression model: Stock price $=$ M2 + IPI + CPI + FX + CD

The values in parenthesis/brackets are critical values at the 0.05 level. Cointegratingequations are significant at the 0.05 level $\left({ }^{*}, p\right.$-value $<0.05$ and ${ }^{* *}, p$-value $\left.<0.01\right)$.

\subsection{Vector Error Correction Estimates}

Considering the results of the Johansen cointegration test in Table 4, it is evident that there is a long-run equilibrium relationship between stock prices and macroeconomic variables in Korea. In this case, an unrestricted vector autoregressive model (VAR) would not be an effective option for testing short-run dynamics. Engle and Granger (1987) noted that if two or more variables are cointegrated, there is always a corresponding error correction representation in which the short-run dynamics of the variables in the system are influenced by the deviation from equilibrium. The cointegrated variables must have an error correction representation in which an error correction term is incorporated into the model. In this case, a vector error correction model is formulated to reintroduce the information lost in the differencing process, thereby allowing for long-run equilibrium as well as short-run dynamics. The vector error correction model (VECM) implies that changes in one variable are a function of the level of disequilibrium in the cointegrating relationship (captured by the error correction term), as well as changes in other explanatory variables. Thus, the vector error correction model is useful for detecting the long-run and short-run elasticity when the variables are cointegrated.

The VECM is a technique that facilitates the capture of both the dynamic and interdependent relationships of the particular variables and is a special type of restricted VAR which can correct a disequilibrium that may shock the whole system. The VECM can distinguish between the short-run and long-run elasticity because it can capture both the short-run and the long-run dynamics. The long-run dynamics are determined by the error correction term. The long-run elasticity is implied by the significance of the t-test of the lagged error correction terms. The multivariate vector error correction model provides t-statistics that are used to interpret the statistical significance of coefficients of the regressors.

Statistical inference is sensitive to parameter instability, serial correlation in residuals and residual skewness. The results of VECM estimates, model diagnostic tests and residual diagnostic tests indicate that there are considerably fewer outliers and the fluctuation bands are smaller. Skewness of the series is not significantly different from a normal distribution. Histogram normality using the JarqueBera test (null hypothesis: residuals are multivariate normal) is rejected. Breusch-Godfrey serial correlation Lagrange multiplier or LM test (null hypothesis: no serial correlation at lag order 2) is rejected. Heteroskedasticity test (null hypothesis: no autoregressive conditional heteroskedasticity or ARCH effect at lag order 1) is also rejected. Thus, this model yields acceptable results. 
Table 5 reports the results of VECM estimates. The insignificance of ECT(t-1) indicates the lagged structure of ECT is stable, that is, no long-run dynamics. In testing hypothesis 2 that money supply(M2) is related to stock prices in the short-run, Table 5 shows that M2 is not significant at the 0.05 level in Korea. Hypothesis 3 states that industry production index (IPI) is related to stock prices in the short-run. The result shows that IPI is significant at the 0.01 level. In addition, the lagged period of IPI has positive influence on stock prices while its two-lagged period has negative influence that outweighs the former. Recall hypothesis 4 that Inflation (CPI) is related to stock prices in the short-run. It is evident that $\mathrm{CPI}$ is negatively significant at the 0.05 level.

Table 5. Results of Vector Error Correction Estimates

\begin{tabular}{|c|c|c|}
\hline Dynamics & $\begin{array}{c}\text { Dependent variable: } \\
\text { KOSPI(t) } \\
\text { Lag order in () } \\
\end{array}$ & \begin{tabular}{|c|} 
Coefficient \\
$\begin{array}{c}\text { Standard errors in ( ); } \\
\text { t-statistics in [ ] }\end{array}$ \\
\end{tabular} \\
\hline $\begin{array}{l}\text { Long-run } \\
\text { dynamics }\end{array}$ & Cointegrating $\mathrm{ECT}_{\mathrm{t}-1}$ & $-0.001(0.000) \quad[-1.347]$ \\
\hline \multirow{15}{*}{$\begin{array}{l}\text { Short-run } \\
\text { dynamics }\end{array}$} & KOSPI(t-1) & $0.422(0.062)^{* *}[6.715]$ \\
\hline & KOSPI(t-2) & $\mid-0.022(0.061) \quad[-0.374]$ \\
\hline & $\mathrm{M} 2(\mathrm{t}-1)$ & \begin{tabular}{|ll}
$0.002(0.007)$ & {$[0.388]$}
\end{tabular} \\
\hline & $\mathrm{M} 2(\mathrm{t}-2)$ & $0.001(0.005) \quad[0.254]$ \\
\hline & $\mathrm{IPI}(\mathrm{t}-1)$ & $1.539(0.652)^{* *}[2.358]$ \\
\hline & $\mathrm{IPI}(\mathrm{t}-2)$ & $-2.023(0.665)^{* \star}[-3.042]$ \\
\hline & $\mathrm{CPI}(\mathrm{t}-1)$ & $-1.648(0.954)^{*}[-1.727]$ \\
\hline & $\mathrm{CPI}(\mathrm{t}-2)$ & $\begin{array}{ll}1.223(0.959) & {[1.275]}\end{array}$ \\
\hline & FX_USD(t-1) & $0.324(0.158)^{\star *}[2.043]$ \\
\hline & $F X \_U S D(t-2)$ & $0.199(0.155) \quad[1.283]$ \\
\hline & $\mathrm{CD}(\mathrm{t}-1)$ & \begin{tabular}{|ll}
$0.013(0.073)$ & {$[0.179]$} \\
\end{tabular} \\
\hline & $C D(t-2)$ & $-0.089(0.070) \quad[-1.265]$ \\
\hline & $\begin{array}{c}\text { External shock } \\
\text { dummy(t-1) }\end{array}$ & $\begin{array}{ll}0.025(0.035) & {[0.732]}\end{array}$ \\
\hline & $\begin{array}{c}\text { External shock } \\
\text { dummy }(\mathrm{t}-2)\end{array}$ & $-0.038(0.034) \quad[-1.096]$ \\
\hline & Determinant & $0.003(0.004) \quad[0.819]$ \\
\hline \multirow{3}{*}{$\begin{array}{c}\text { Model diagnostic } \\
\text { tests }\end{array}$} & R-squared & 0.222 \\
\hline & Adjusted R-squared & 0.183 \\
\hline & F-statistic & $5.758^{* *}$ \\
\hline \multirow{3}{*}{$\begin{array}{c}\text { Residual } \\
\text { diagnostic tests }\end{array}$} & $\begin{array}{c}\text { Breusch-Godfrey serial } \\
\text { correlation LM test F- } \\
\text { statistic }\end{array}$ & $\begin{array}{l}74.443^{* *} \\
\text { (Lags 2; } \quad \text { df }=49)\end{array}$ \\
\hline & \begin{tabular}{|c|}
$\begin{array}{c}\text { Heteroskedasticity } \\
\text { test: } \\
\text { ARCH effect F-statistic }\end{array}$ \\
\end{tabular} & $\begin{array}{c}1112.508^{\star *} \\
(\mathrm{df}=840)\end{array}$ \\
\hline & $\begin{array}{c}\text { Histogram nomality } \\
\text { test: } \\
\text { Jarque-Bera test } \\
\text { statistic }\end{array}$ & $\begin{array}{c}128035.301^{* *} \\
(\mathrm{df}=14)\end{array}$ \\
\hline
\end{tabular}

Note: The probability value for rejection of the null hypothesis is employed at the 0.05 level $\left({ }^{*} p<0.05\right.$ and $\left.{ }^{* *}, p<0.01\right)$.
Furthermore, with respect to hypothesis 5 that exchange rate is related to stock prices in the short-run, the estimated model reveals that exchange rate (Korean Won/USD) is positively and significantly related to stock prices in the short-run at the 0.01 level. According to hypothesis 6 that short-term interest rate (CD) is related to stock prices in the short-run, the empirical evidence indicates the short-term interest rate is insignificant at the 0.05 level. Finally, hypothesis 7 postulates that external shocks are related to stock price dynamics in the short-run. For Korea case, external shocks are not significant at the 0.05 level in Korea (Table 5).

\subsection{Impulse Responses}

In addition to the findings corresponding to the above hypotheses, the impulse responses and variance decomposition may be noteworthy in their impact. A shock to the $j$-th variable not only directly affects that variable but is also transmitted to all of the other endogenous variables through the dynamic (lag) structure of the vector autoregressive. The effects of the shocks on the endogenous variables can be assessed by estimating impulse responses and variance decomposition functions. An impulse response function traces the effect of a one-time shock to one of the innovations on current and future values of the endogenous variables. Since innovations are usually correlated, it may be viewed as having a common component that cannot be associated with a specific variable. In order to interpret the impulses, it is common to apply a transformation to the innovations that cause them to become uncorrelated. The Cholesky transforming method uses the inverse of the Cholesky factor of the residual covariance matrix to orthogonalize the impulses. This method imposes an ordering of the variables in the vector autoregressive and attributes all of the effect of any common component to the variable that comes first in the vector autoregressive system. For stationary vector autoregressive models, the impulse responses should die out to zero and the accumulated responses should be asymptote to some constant.

Figure 1 presents the results of the impulse responses of stock prices to Cholesky one standard deviation innovations of four significant endogenous variables: stock price (KOSPI), industry production index (IPI), inflation (CPI) and exchange rates (FX_USD). The response of stock prices itself to each shock shows a positive impact throughout with an increase in the first four months, and stabilizing afterwards. Although, the response of stock prices to IPI increases which also has a positive impact in the first few months, but when the response reaches the upper turning point, it gradually declines into a negative zone. The 
Response to Cholesky One S.D. Innovations

Response of KOSPI to KOSPI

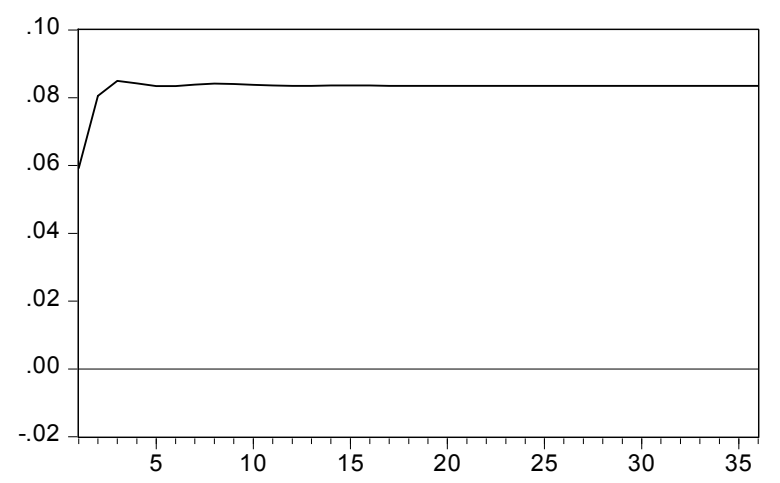

Response of KOSPI to CPI

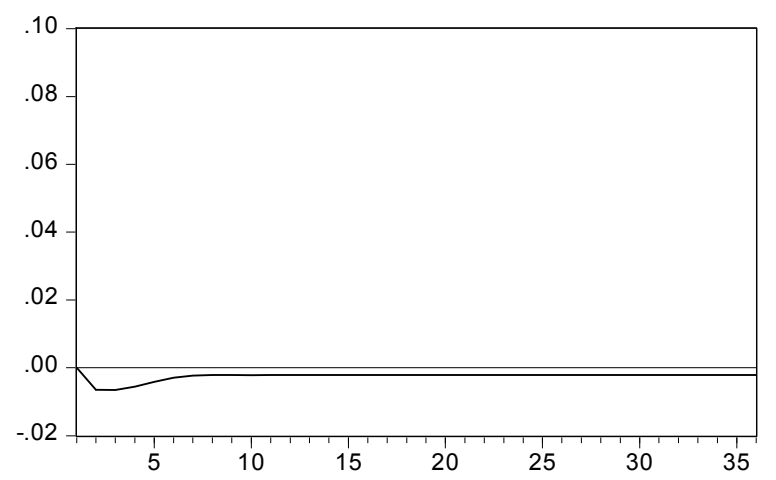

Response of KOSPI to IPI

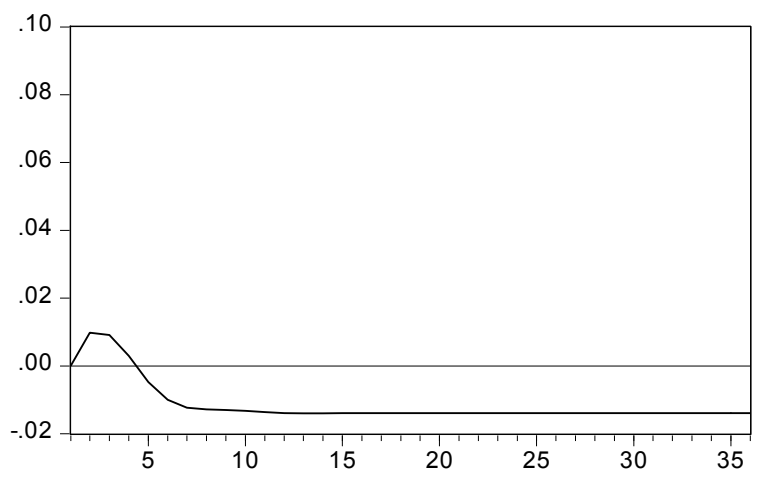

Response of KOSPI to USD

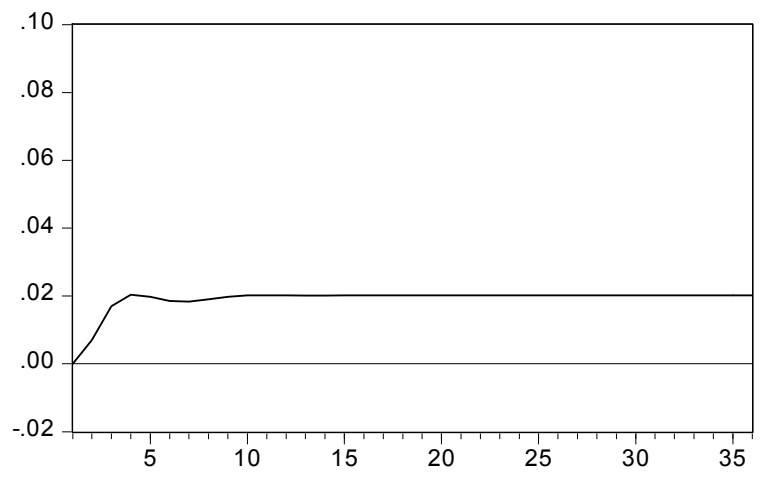

Note: The confidence bands are computed using the $95 \%$ confidence intervals. When displaying the graphs in a VEC model, standard error bands will not be displayed. The graphs are displayed in 36 periods with two lags.

Figure 1. Impulse Response of KOSPI to Innovations of Selected Macroeconomic Variables

stabilization does not take place until after about 10 months. Alternately, the response of stock prices to CPI decreases in the first few months, then rises in subsequent periods and ultimately leveling off after seven months. However, the effect at full length is negative. The influence of stock prices on exchange rates (FX_USD) in the short run is positive, all through, increasing around the first four months prior to stability for the duration. Hence, these results indicate that Korea stock prices are largely determined by its own shock and exchange rate shock.

\section{Discussion and Policy Implication}

This research contributes to the existing literature in three main aspects. First, this research uncovers the fact that there exists a long-run equilibrium relationship between macroeconomic variables and stock prices in the Korean stock market. Second, the paper empirically explores the short-term dynamic relationships between selected macroeconomic variables and stock prices as follows:

- For stock prices (KOSPI) itself, the lagged period of stock prices has positive influence on current period while the two-lagged period of GDP shows no significant influence on current period. This may prompt investors not to base their expectations of future results on past performance. The likelihood of various stock price outcomes are hypothetical in nature and everybody should realize about the ups and downs of stock market.

- Industry production index (IPI) is related to stock prices in the short-run. However, the lagged period of IPI has a positive influence on stock prices while its twolagged period has a negative influence that outweighs 
the former. While the first-order lag of the IPI coefficient is positive, the absolute value of the second-order lag coefficient is larger. In effect, high IPI growth raises stock prices in the early stage of production and eventually reverse its course due in part to diminishing returns. Case in point, this result supports Brahmasrene and Jiranyakul (2007)'s research that throughout the crisis, capacity utilization and the industrial production index declined as firms were reluctant to expand their levels of production. In spite of a decline in the industrial production index, the stock market index continued to rise because speculative motive in financial and real estate sectors dominated the buy and hold strategy.

- Inflation (CPI) is negatively related to stock prices in the short-run with a significant coefficient of -1.648 . This means that the system corrects its previous period disequilibrium 1.65 times reflecting a sizable speed of adjustment to reach equilibrium steady state position. A similar study for Pakistan by Ahmad, Ahmad, Khan and Javaid (2012) also substantiates this outcome. Rising inflation causes an insidious effect because production costs are higher, consumers can purchase fewer goods due to reduction in purchasing power, firms' revenues and profits decline resulting in firms' value and stock prices. By any stretch of imagination, monetary authority and businesses must constantly monitor inflation since if left unchecked, it could spike and would likely cause deceleration in the economy.

- The estimated value of exchange rates (Korean won per USD) is 0.358 . This short run coefficient also represents the short run equilibrium. It implies the rate at which the previous period disequilibrium of the system is being corrected. Thus, the system corrects its previous period disequilibrium at a speed of 35.8 percent between exchange rates and the Korean stock prices. This confirms findings by Kabir, Bashar and Masih (2014) and Hussin, Muhammad, Abu and Awang (2012) employing data from Malaysia. During period under study, a depreciation of the Korean won makes Korean exports more competitive but raises the cost of importing goods into Korea. This results in a decline in imports and an increase in exports. Hence, domestic firms will benefit from increased sales. An increase in exports raise profits and the firms' value along with stock prices. The increased demand for stocks drives prices up further when investors shift their portfolio from bonds to stocks to profit from rising stock prices. This is a whole new take that the monetary authorities of East Asian countries should care about not only the US dollar and the euro, but also the Korean won, because Korea has a larger role in intra-regional economic relations.

Finally, there is no compelling evidence that the external shocks such as regional or global financial crisis have impact on the stock price dynamics in the Korean stock market. In light of these findings, financial managers can enhance their understanding of the short-run movements of industry production, inflation, exchange rates and stock price dynamics. A better understanding of these short -run and long-run movements enables financial managers to make well informed investment and financial decisions.

\section{Conclusions}

Recommendations can be drawn from the findings presented in this paper. From a long-term perspective, policymakers should consider selected macroeconomics such as money supply, industrial production index, inflation, exchange rates and interest rates as policy tools aiming at the Korean stock market since the results show evidence of a long-run equilibrium relationship among them. However, from a short-term perspective, policymakers may consider the industrial production index, inflation and the exchange rates as policy tools to manage and control the Korean stock market since these variables, to some extent, may cause an adverse effect on stock prices in Korea. This policy should be effective in the short-run then be evaluated in the future.

On the contrary, the results acknowledge that money supply and interest rates exhibit no relationship on stock prices in Korea. It would appear that this independent behavior of the stock market could be a state of the market liberalization process for its economy to heal and propel itself toward long-run stability and a better future of the Korean stock market. Therefore, policymakers and investors should devote more time and effort acquiring not only the information on changes in monetary policy and temporary external shocks in the short-run, but also the knowledge and information about the market itself.

Further research may be directed at some of the above issues. The empirical model may be estimated with alternative economic and financial factors or markets. Studies encompassing different economies should be conducted where data is available. Such research should contribute toward improving our understanding of the market mechanism and responses of each market to the frequently occurring phenomena of economic and financial crisis, whether regional or global. 


\section{References}

Agrawalla, R. K., \& Tuteja, S. K. (2008). Share Prices and Macroeconomic Variables in India: An Approach to Investigate the Relationship Between Stock Markets and Economic Growth. Journal of Management Research, 8(3), 136-146.

Ahmad, Z., Ahmad, Z., Khan, M. S., \& Javaid, U. (2012). Capturing the stock price movements at Karachi Stock exchange: Are macroeconomic variables relevant? African Journal of Business Management, 6(8), 3026-3034.

Al-Majali, A. A., \& Al-Assaf, G. I. (2014). Long-Run And Short-Run Relationship Between Stock Market Index And Main Macroeconomic Variables Performance In Jordan. European Scientific Journal, 10(10), 156-171. Retrieved May 10, 2017 from http://eujournal.org/index.php/esj/article/viewFile/312 9/2927

Alrub, A. A., Tursoy, T., \& Rjoub, H. (2016). Exploring the Long-run and Short-run Relationship between Macroeconomic Variables and Stock Prices during the Restructuring Period: Does it Matter in Turkish Market? Journal of Financial Studies \& Research, 2016, 1-11.

Bahmani-Oskooee, M., \& Saha, S. (2015). On the relation between stock prices and exchange rates: a review article. Journal of Economic Studies, 42(4), 707-732.

Basistha, A., \& Kurov, A. (2008). Macroeconomic Cycles and the Stock Market's Reaction to Monetary Policy. Journal of Banking \& Finance, 32, 2606-2616.

Bilson, C. M., Brailsford, T. J., \& Hooper, V. J. (2009). Selecting Macroeconomic Variables as Expanatory Factors of Emerging Stock Market Returns. PacificBasin Finance Journal, 9, 401-426.

Bjornland, H. C., \& Leitemo, K. (2009). Identifiying the Interdependence between the US Monetary Policy and the Stock Market. Journal of Monetary Economics, 56, 275-282.

Brahmasrene, T., \& Jiranyakul, K. (2007). Cointegration and Causality between Stock Index and Macroeconomic Variables in an Emerging Market. Academy of Accounting and Financial Studies Journal, 11(3), 1730.

Brahmasrene, T., Huang, J-C. \& Sissoko, Y. (2014). Crude oil prices and exchange rates: Causality, variance decomposition and impulse response. Energy Economics, 44, 407-412.

Branson, W., Halttunen, H., \& Masson, P. (1977). Exchange rate in the short run: the dollar Deutsche mark rate. European Economic Review, 10, 303-324.
Büyükşalvarci, A., \& Abdioğlu, H. (2010). The Causal Relationship between Stock Prices and Macroeconomic Variables: A Case Study for Turkey. International Journal of Economic Perspectives, 4(4), 601-610.

Cheung, Y. W., \& Lai, K. S. (1993). Finite-sample sizes of Johansen's likelihood ratio tests for cointegration. Oxford Bulletin of Economics and Statistics, 55, 313328.

Dickey, D. A., \& Fuller, W. A. (1979). Distribution of the estimators for autoregressive time series with a unit root. Journal of the American Statistical Association, 74, 427-431.

Dickey, D. A., \& Fuller, W. A. (1981). Likelihood ratio statistics for autoregressive time series with a unit root. Econometrica, 49, 1057-1071.

Dornbusch, R., \& Fisher, S. (1980). Exchange rates and the current account. American Economic Review, 70(5), 960-971.

Engle, R. F., \& Granger, C. W. J. (1987). Cointegration and error correction: Representation, estimation and testing. Econometrica, 55, 251-276.

Gay, R. D. (2016). Effect Of Macroeconomic Variables On Stock Market Returns For Four Emerging Economies: Brazil, Russia, India, And China. International Business \& Economics Research Journa, 15(3), 119126.

Granger, C. W. J. (1988). Some recent developments in a concept of causality. Journal of Econometrics, 39, 199-211.

Hahm, J. H. (2005). The Resurgence of Banking Institutions in Post-crisis Korea. Journal of Contemporary Asia, 35(3), 386-403. https://doi.org/10.1080/00472330580000221

Hussainey, K., \& Ngoc, L. K. (2009). The impact of macroeconomic indicators on Vietnamese stock prices. The Journal of Risk Finance, 10(4), 321-332.

Hussin, M. Y. M., Muhammad, F., Abu, M. F., \& Awang, S. A. (2012). Macroeconomic Variables and Malaysian Islamic Stock Market: A Time Series Analysis. Journal of Business Studies Quarterly, 3(4), 1-13.

loannidis, C., \& Kontonikas, A. (2008). The impact of monetary policy on stock prices. Journal of Policy Modeling, 30, 33-53.

Jansen, D. W., \& Tsai, C.-L. (2010). Monetary Policy and Stock Returns: Financing Constraints and Asymmetries in Bull and Bear Markets. Journal of Empirical Finance, 17, 981-990.

Johansen, S. (1988). Statistical analysis of cointegration vectors. Journal of Economic Dynamics and Control, 12, 231-254. 
Kabir, S. H., Bashar, O. K., \& Masih, A. M. (2014). Is Domestic Stock Price Cointegrated With Exchange Rate And Foreign Stock Price? Evidence From Malaysia. The Journal fo Developing Areas, 48(3), 285-302.

Kim, H., Kim, J., Lee, J., \& Ryu, D. (2014). The impact of monetary policy on banking and finance stock prices in China. Applied Economics Letters, 21(18), 12571261.

Kotha, K. K., \& Sahu, B. (2016). Macroeconomic Factors and the Indian Stock Market: Exploring Long and Short Run Relationships. International Journal of Economics and Financial Issues, 6(3), 1081-1091.

Kumar, A. (2011). An Empirical Analysis of Causal Relationship Between Stock Market And Macroeconomic Variables In India. International Journal of Computer Science \& Management Studies, 11(1), 8-14.

Kwiatkowski, D., Phillips, P. C. B., Schmidt, P., \& Shin, Y. (1992). Testing the null hypothesis of stationary against the alternative of a unit root. Journal of Econometrics, 54, 159-178.

Laeven, L., \& Tong, H. (2012). US Monetary Shocks and Global Stock Prices. Journal of Finanantial Intermediation, 21, 530-547.

$\mathrm{Li}, \mathrm{J}$. (2015). The asymmetric effects of investor sentiment and monetary policy on stock prices. Applied Economics, 47(24), 2514-2522.

Li, Y. D., Iscan, T. B., \& Xu, K. (2010). The Impact of Monetary Policy Shocks and Stock Prices: Evidence from Canada and the Unites States. Journal of International Money and Finance, 29, 876-896.

Lim, S. H. (2005). Foreign Capital Entry in the Domestic Banking Market of Korea: Bitter Medicine or Poison. Korean Political Science Review, 39(4), 189-209. (In Korean).

MacKinnon, J. G. (1996). Numerical distribution functions for unit root and cointegration tests. Journal of Applied Econometrics, 11, 601-618.

Mackinnon, J. G., Haug, A. A., \& Michelis, L. (1999). N umerical distribution functions of likelihood ratio te sts for cointegration. Journal of Applied Economet rics, 14, 563-577.

Mangala, D., \& Rani, A. (2015). Revisiting the Dynamic Relationship between Macroeconomic Fundamentals and Stock Prices: An Evidence from Indian Stock Market. International Journal of Financial Management, 5(3), 53-63.
Sangmi, M.-M., \& Hassan, M. M. (2013). Macroeconomic Variables on Stock Market Interactions: The Indian Experience. IOSR Journal of Business and Management, 11(3), 15-28.

Newey, W., \& West, K. (1994). Automatic lag selection i $\mathrm{n}$ covariance matrix estimation. Review of Econo mic Studies, 61, 631-653.

Peiro, A. (2016). Stock Prices and Marcoeconomic Factors: Some European Evidence. International Review of Economics and Finance, 41, 287-294.

Phillips, P. C. B., \& Perron, P. (1988). Testing for a unit root in time series regression. Biometrica, 75(2), 335-346.

Pirovano, M. (2012). Monetary Policy and Stock Prices in Small Open Economies: Empirical Evidence for the new EU Member States. Economic Systems, 36, 372-390.

Raja, J., \& Kalyanasundaram, M. (2010). A Study On The Relationship Between Stock Market Index And Economic Variables Among Emerging Economies. The Journal Contemporary Management Research, 4(2), 1-7.

Sampath, T. (2011). Macroeconomic Variables and Stock Prices in India: An Empirical Analysis. The IUP Journal of Monetary Economics, 9(4), 43-55.

Singh, T., Mehta, S., \& Varsha, M. S. (2011). Macroeconomic factors and stock returns: Evidence from Taiwan. Journal of Economics and International Finance, 2(4), 217-227.

Tang, Y., Luo, Y., Xiong, J., Zhao, F., \& Zhang, Y.-C. (2013) Impact of monetary policy changes on the Chinese monetary and stock markets. Physica A, 392, 44354449.

Vithessonthi, C., \& Techarongrojwong, Y. (2012). The Impact of Monetary Policy Decision on Stock Returns: Evidence from Thailand. Journal of International Financial Markets, Institutions and Money, 22, 487507.

Zare, R., Azali, M., \& Habibullah, M. S. (2013). Monetary Policy and Stock Market Volatility in the ASEAN5: Asymmetries over Bull and Bear Markets. Procedia Economics and Finance, 7, 18-27.

Zhao, H. (2010). Dynamic relationship between exchange rate and stock price: Evidence from China. Research in International Business and Finance, 24(2), 103112. 